Joanna Smakulska

Uniwersytet w Białymstoku, Białystok

ORCID: 0000-0001-5482-8047

e-mail: j.smakulska@uwb.edu.pl

\title{
O nieracjonalności potępiania samobójstwa w poglądach Davida Hume'a i Jamesa Hillmana
}

\author{
Nikt nigdy nie wyrzekt się życia, \\ kiedy warto było jeszcze sie go trzymać. \\ David Hume \\ Samobójstwo jest możliwościa dana człowiekowi. \\ Śmierć można wybrać* \\ James Hillman
}

David Hume (1711-1776), szkocki filozof i historyk, oraz James Hillman ${ }^{1}$ (1926-2011), amerykański filozof i psycholog, byli przeciwnikami potępiania czynu samobójczego w wymiarze społecznym i jednostkowym. Zakaz samobójstwa jest uderzeniem w przyrodzoną wolność człowieka. Można uznać, że w kwestii nieracjonalności zakazu samobójstwa ich poglądy wykazują zbieżność, uzupełniają się, a u Hillmana zostają pogłębione z perspektywy psychoanalitycznej. Hillman także powołuje się na

" David Hume, „Esej o samobójstwie”, w: David Hume, Dialogi o religii naturalnej. Naturalna historia religii wraz $z$ dodatkami, przeł. Anna Hocheldowa (Warszawa: Wydawnictwo PWN, 1962), 232.

** James Hillman, Samobójstwo a przemiana psychiczna, przeł. Dariusz Rogalski (Warszawa: Wydawnictwo KR, 1996), 43.

${ }^{1}$ Hillman wywodzi się ze szkoły jungowskiej, jest między innymi autorem książki znanej w Polsce pt. Kod duszy. W poszukiwaniu charakteru człowieka i jego powołania (Warszawa: Wydawnictwo Laurum, 2014). 
samego Hume'a, który swoje poglądy w tej kwestii zawarł w eseju $O$ samobójstwie ${ }^{2}$. Odniósł się w nim do wszystkich zwyczajowych argumentów na rzecz potępiania samobójstwa w celu wykazania nieracjonalności zakazu godzącego w ludzką wolność ${ }^{3}$. Natomiast Hillman w książce pt. Samobójstwo a przemiana psychiczna poszukuje źródeł potępienia w sferze archetypowej. W przypadku Hume'a argumentacja odnosząca się do nieracjonalności zakazu samobójstwa opiera się na prawie natury, u Hillmana zaś na jego koncepcji duszy ${ }^{4}$.

Problem prawa do samobójstwa ujmowany w kategoriach moralnych jest podejmowany od stuleci; na różne sposoby uzasadniano przyzwolenie lub potępienie, nigdy jednak bezwarunkowo. Zakaz czynu suicydalnego nie jest specyfiką myśli chrześcijańskiej, gdyż już w tradycji orfickiej uważano, że człowiek nie ma prawa odebrać sobie życia. Ten pogląd był głoszony w starożytności przez pitagorejczyków, Platona czy Sokratesa ${ }^{5}$. Z rodzaju relacji między Bogiem i człowiekiem wynikało uzasadnienie zakazu decydowania o momencie własnej śmierci. Sokrates w platońskim dialogu Fedon, odnosząc się do swojej sytuacji, mówi o pewnego rodzaju konieczności, w której sam się znalazł: „Więc może tak samo nie jest i to bez sensu, że nie wolno siebie samego zabijać prędzej, zanim Bóg nie ześle jakiejś konieczności, jak na przykład ta, którą ja mam teraz"6. Wypicie przez niego trującej cykuty okazuje się taką właśnie „koniecznością". Platon w Prawach wymienia więcej przykładów usprawiedliwień samobójstwa, na przykład hańbę czy nieprzemijające nieszczęścia, lecz nawet gdy uzasadniają one śmierć, to jego zdaniem

${ }^{2}$ Brunon Hołyst zauważa, że to dzieło jest właściwie całym traktatem na temat samobójstwa, który Hume nazwał esejem (Essay on Suicide). Ukazał się on po śmierci autora w 1783 roku ze względu na obawy dotyczące nietolerancji otoczenia. Zdaniem Hołysta w metodologicznym ujęciu esej stanowi egzemplifikację postulowanej przez Hume'a etyki opisowej, a także psychologicznego wyjaśniania genezy religii. Hume uważał zakaz samobójstwa za pogwałcenie przyrodzonego przywileju ludzkiej wolności. Zob. Brunon Hołyst, Suicydologia, wydanie 2 (Warszawa: Wydawnictwo Lexis Nexis, 2012), 137.

3 Zob. Hume, „Esej”, 223.

4 „W polu mojego zainteresowania znajduje się więc psychologia duszy, która bazuje na psychologii obrazu. Dlatego postuluję zarówno istnienie poetyckiej bazy umystu, jak i psychologii, która zaczyna nie od fizjologii mózgu, struktury języka, organizacji społeczeństwa czy analizy zachowania, lecz od procesów imaginacji"; James Hillman, Re-wizja psychologii, przeł. Jerzy Korpanty (Warszawa: Wydawnictwo Laurum, 2016), 27.

${ }_{5}$ Zob. Jerzy Kopania, Boski sen o stworzeniu świata. Szkice filozoficzno-teologiczne (Białystok: Wydawnictwo Trans Humana, 2003), 99 i n.

6 Platon, „Fedon” 62C, w: Platon Dialogi, t. 1, przeł. Władysław Witwicki (Kęty: Wydawnictwo Antyk, 1999), 633. 
samobójstwo nie staje się przez to czynem dobrym. W tradycji pitagorejsko-platońskiej jest ono istotowo zawsze złem7.

W naszej cywilizacji niesłusznie zatem uznaje się Biblię za źródło zakazu samobójstwa. Stary Testament wymienia nawet kilka pozytywnych przykładów samobójców, a w Nowym Testamencie nie ma potępienia czynu suicydalnego. Paradoksalnie, pierwsi chrześcijanie tak obsesyjnie myśleli o śmierci, a jednocześnie tak bardzo bali się popełnienia grzechu, że doprowadzało ich to do wyboru śmierci samobójczej, aby zapobiec w ten sposób sposobności do zgrzeszenia. Dla Rzymian fakt śmiertelności nie był istotny, tym zaś, co ważne, był sposób umierania jako wyznacznik ostatecznej wartości życia. Chrześcijanie przejęli od Rzymian obojętną postawę wobec śmierci, choć patrzyli na nią z odmiennej perspektywy. Stoicy dopiero w ostateczności odbierali sobie życie i zauważmy, że tylko taka ewentualność była w rozumieniu Davida Hume'a usprawiedliwiona. Dla pierwszych chrześcijan samobójstwo stanowiło ucieczkę do lepszego świata, wyzwolenie od pokus doczesności i możliwości popełnienia grzechu ${ }^{8}$.

W początkowym okresie istnienia chrześcijaństwa samobójstwo nie było czynem potępianym, a wręcz przeciwnie - dążenie do wieczności powodowało liczne śmierci samobójcze traktowane jako akty męczeństwa. Taka sytuacja zaczęła wzbudzać niepokój i sceptycyzm Ojców Kościoła. Pierwszym chrześcijańskim myślicielem zdecydowanie potępiającym samobójstwo był Augustyn, który wyraził swoje stanowisko w dziele Państwo Boże (De civitate Dei). Znalazło się tam stanowcze utożsamienie samobójstwa z zabójstwem: „kto i sam sobie życie odbiera, zabójcą jest" ${ }^{\prime \prime}$. Samobójca zasługuje na najwyższe potępienie, ponieważ jest grzesznikiem odrzucającym możliwość pokuty ${ }^{10}$. Z biegiem czasu owa dezaprobata wśród chrześcijan przybiera na sile. W 452 roku synod w Arles potępia samobójstwo; tak też dzieje się i na kolejnych synodach.

W myśli chrześcijańskiej Augustyn był pierwszym twórcą zarysu filozoficznej teorii samobójstwa i przez wiele wieków jedynym. W najbardziej kompleksowy sposób wypowiadał się w kwestii samobójstwa jako

7 Zob. Kopania, Boski sen, 100.

8 Zob. Hołyst, Suicydologia, 104-105.

9 Augustyn, Państwo Boże, przeł. ks. Tadeusz Kubicki (Kęty: Wydawnictwo Marek Derewiecki, 2015), 41. Augustyn także w pierwszym tomie Państwa Bożego pisze: "człowiekowi nie wolno zabijać siebie samego, skoro od tego zakazu, który brzmi: »Nie zabijaj«, bez żadnego dodatku, nie może być oczywiście wyjęty i sam ten, któremu przykazanie dano"; tamże, 45.

${ }_{10}$ Augustyn o samobójczej śmierci Judasza napisał: „wieszając się, nie tylko nie odpokutował za ową przez się popełnioną ohydną zdradę, lecz raczej winę jej powiększył, ponieważ poniechawszy w rozpaczy miłosierdzie Boże i czyniąc pokutę zatracenia, nie pozostawił sobie żadnego wyjścia ku pokucie zbawiennej"; Augustyn, Państwo, 41. 
aktu bezwzględnie zakazanego ${ }^{11}$. Poglądy Augustyna, a potem Tomasza z Akwinu, uznającego samobójstwo za grzech śmiertelny, sprzeczny z prawem natury i miłością ${ }^{12}$, zadecydowały o jednoznacznym potępieniu samobójców, utrzymującym się aż do przełomu XVII i XVIII wieku. Wraz z powstaniem naturalistycznych koncepcji zaczął zmniejszać się rygoryzm jednoznacznego zakazu, a pojawiły się inne postawy inspirowane przynajmniej po części starożytną apoteozą samobójstwa. David Hume stał się kluczowym orędownikiem tego nowego podejścia ${ }^{13}$. W czasach nowożytnych to moralistyka chrześcijańska wydaje się głównym źródłem bezwzględnego potępienia samobójstwa. W okresie średniowiecza samo słowo „samobójstwo" jeszcze nie występowało. Pojawiło się w 1734 roku we Francji, a sto lat wcześniej filozofowie angielscy użyli słowa suicidium jako łacińskiego neologizmu ${ }^{14}$ : „Słowo to zostało utworzone dopiero na progu rewolucji przemysłowej, gdy samobójców przestano już uważać za morderców, dostrzegając w ich czynach akt jednostkowej woli"15. Wcześniej samobójstwo było traktowane jako odmiana zabójstwa i naruszenie piątego przykazania, „Nie zabijaj”16, a więc było rozumiane tak, jak interpretował je Augustyn.

Potępianie samobójstwa przez religię i filozofię ma ogromny wpływ na ustawodawstwo świeckie, które wdrożyło przeróżne sposoby bezczeszczenia zwłok samobójców, takie jak na przykład: palenie na stosie, wieszanie, łamanie kołem, wleczenie nagich ciał po ulicach. Takie praktyki miały miejsce nie tylko w wiekach średnich, ale przetrwały do czasów nowożytnych. Posuwano się nawet do tego, że zakazany był normalny pochówek, a majątek samobójców konfiskowano. W Anglii ostatni odnotowany przypadek zbezczeszczenia zwłok (przedziurawienia żerdzią) ciała samobójcy i pochowania go na skrzyżowaniu dróg pochodzi z 1823 roku $^{17}$.

11 Zob. Hołyst, Suicydologia, 112-113 i 152.

12 Tomasz napisał: „samobójstwo jest zawsze grzechem śmiertelnym, jako sprzeczne z prawem natury oraz z miłością. [...] Popełniając więc samobójstwo, czyni się krzywdę społeczności. [...] Kto więc pozbawia się życia, grzeszy przeciw Bogu. [...] Sam tylko Bóg ma prawo wyrokować o życiu i śmierci"; Tomasz z Akwinu, Suma teologiczna w skrócie (Wydawnictwo Antyk - Marcin Dybowski, Warszawa 2006), II-II, 64, 502. Zob. też Etienne Gilson, Tomizm. Wprowadzenie do filozofii św. Tomasza z Akwinu, przeł. Jan Rybałt (Instytut Wydawniczy PAX, Warszawa, 1998).

13 Zob. Hołyst, Suicydologia, 152-155.

14 Zob. Stefan Chwin, Samobójstwo jako doświadczenie wyobraźni (Gdańsk: Wydawnictwo Tytul, 2016), 66 i 430.

15 Tamże, 66.

16 Zob. Roman Tokarczyk, Prawa narodzin, życia i śmierci. Etyczne problemy wspótczesności (Lublin: Wydawnictwo Lubelskie, 1984), 267.

17 Zob. Hołyst, Suicydologia, 172-173. Pomysłodawcą tego typu karania samobójcy był prawnik, sir William Blackstone. W swoim dziele Commentaries on the Law of 
Pochwała autonomii człowieka w czasach nowożytnych stworzyła odpowiedni klimat do pojawienia się głosów usprawiedliwiających obok tych jednoznacznie potępiających - samobójców. Za czyn etycznie niedopuszczalny uznawali samobójstwo między innymi Immanuel Kant i Georg W. F. Hegel, natomiast prawa do samobójstwa domagali się na przykład Montesquieu, Jean-Jacques Rousseau, David Hume czy Artur Schopenhauer ${ }^{18}$.

David Hume w swoim eseju O samobójstwie, występując przeciwko bezwzględnemu jego potępianiu, postawił sobie za cel obronę i przywrócenie ludzkiej przyrodzonej wolności, na której przeszkodzie stoją przesądy. Filozof pisze: „Spróbujmy więc przywrócić tu ludziom ich przyrodzoną wolność, rozpatrując wszystkie argumenty wysuwane zazwyczaj przeciw samobójstwu i okazując, że czyn ten uznać można za wolny od wszelkiego grzechu i przewiny, tak jak sądzili go wszyscy filozofowie starożytni"19. Hume był przeciwnikiem religijnego uzasadniania moralności, co jest dość oczywiste, gdy weźmiemy pod uwagę antyreligijne postawy w epoce Oświecenia. Danuta Ślęczek-Czakon sądzi, że jego poglądy można wpisać w umiarkowany racjonalizm oraz umiarkowany utylitaryzm ${ }^{20}$ : „Etykę chciał uwolnić od zabobonu, przesądu, nieliczenia się z faktami, codziennym ludzkim doświadczeniem (chciał uczynić z niej naukę doświadczalna, autonomiczną - w sensie niezależności od religii)"21.

Hume był myślicielem żyjącym i działającym w epoce Oświecenia, której jednym z głównych postulatów była „walka z ciemnotą i zacofaniem”. Zbigniew Drozdowicz pisze: „Jednym z najbardziej eksponowanych i eksploatowanych był motyw dążenia do osiągnięcia możliwie największej rozumności oraz idea rozumu jako tej ludzkiej zdolności, która może i powinna być arbitrem we wszystkich istotnych życiowo sprawach"22. Umysł człowieka powinien być wolny od ciemnoty, nietolerancji i fanatyzmu ${ }^{23}$. Z całą pewnością należy uznać Hume'a za orędownika tego trendu oświeceniowego. Zakaz samobójstwa uważał za rodzaj zabobonu, na które najlepszym lekarstwem jest filozofia: „Jedna

England, w piętnastym wydaniu (Londyn 1809), zaliczył samobójstwo do najcięższych zbrodni, jako wymierzone przeciwko Bogu i królowi; zob. Hillman, Samobójstwo, 25.

18 Zob. Marian Machinek MSF, Śmierć w dyspozycji człowieka. Teologia moralna wobec problemów etycznych u kresu życia ludzkiego (Olsztyn: Wydawnictwo Wyższego Seminarium Duchownego Metropolii Warmińskiej „Hosianum”, 2001), 90.

19 Hume, „Esej”, 223.

${ }^{20}$ Zob. Danuta Ślęczek-Czakon, „Etyka Davida Hume'a: założenia, wnioski, możliwości interpretacyjne", Folia Philosophica 12 (1994): 140.

21 Tamże.

22 Zbigniew Drozdowicz, Filozofia Oświecenia (Warszawa: Wydawnictwo Naukowe PWN, 2006), 10.

${ }^{23}$ Zob. tamże, 40-41. 
z poważnych korzyści, jakie płyną z filozofii, polega na tym, że dostarcza ona najlepszego antidotum przeciw zabobonowi i fałszywej religii" ${ }^{24}$.

Hume, mówiąc o destrukcyjnym wpływie zabobonu na ludzkie życie, zgodnie z Cyceronem ${ }^{25}$ głosi, że człowiek przesądny jest zawsze nieszczęśliwy, niezależnie od tego, co go spotyka. Zabobon sprawia, że człowiek nie może podjąć decyzji odejścia z życia, nawet gdy bardzo cierpi. Hume ujmuje tę myśl następująco:

chociaż całkowity kres jego niedoli położyć może jedynie śmierć, nie odważa się on przecież szukać w niej ucieczki, ale przeciąga żałosny swój żywot w próżnej obawie, by nie obrazić swojego twórcy, skorzystawszy z władzy, którą dobroczynna owa istota go obdarzyła. Okrutny ten wróg [zabobon] wydziera nam to, co dał nam Bóg i przyroda, a chociaż wystarczy jeden krok, aby opuścić ten padół cierpienia i smutku, groźby zabobonu przykuwają nas do obmierzłego bytowania, do którego niedoli ten sam zabobon głównie się przyczynia ${ }^{26}$.

Hume określa zabobon mianem zjadliwej trucizny zatruwającej ludzkie życie ${ }^{27}$.

Podstawową tezę Hume'a w jego rozważaniach na temat samobójstwa stanowi twierdzenie, że nie jest ono przestępstwem i w związku z tym powszechne bezwzględne potępienie samobójców trzeba uznać za nieracjonalne. Filozof sądzi, że samobójstwo nie jest wykroczeniem ani przeciwko Bogu, ani społeczeństwu, ani sobie samemu.

Najwięcej uwagi poświęca teologicznemu ${ }^{28}$ zakazowi czynu suicydalnego. Stanowczo twierdzi, że „samobójstwo nie jest wykroczeniem przeciw naszej powinności wobec Boga"29. Zarzut teologów wobec samobójcy to rzekome wkraczanie człowieka w kompetencje Boga i ingerowanie w ustanowiony przez Stwórcę ład, w którym człowiek nie ma prawa do swobodnego dysponowania swoim życiem. Hume był całkowicie przekonany, że samobójstwo nie narusza boskiego planu,

${ }^{24}$ Hume, ,Esej”, 221.

25 Zob. Marek Tuliusz Cyceron, „O wróżbiarstwie”, w: Marek Tuliusz Cyceron, O naturze bogów; O wróżbiarstwie; O przeznaczeniu, przeł. Wiktor Kornatowski (PWN: Warszawa, 1960), 2, 72, 149-150.

${ }^{26}$ Hume, „Esej”, 222.

27 Zob. tamże, 221.

${ }^{28}$ Hume sądzi, że samobójstwo nie jest sprzeczne z obrządkiem chrześcijańskim: „Przykazanie nie zabijaj w oczywisty sposób wykluczyć ma jedynie zabijanie innych, nad których życiem nie mamy władzy. Że przykazanie to, podobnie jak większość przykazań Pisma świętego, modyfikować powinien rozum i zdrowy rozsądek - to jasno wynika z praktyki władz sądowych, które skazują przestępców na karę śmierci, pomimo tego, co mówi litera prawa"; tamże, 233.

29 Tamże, 223. 
ponieważ żadne działania człowieka nie mogą zakłócić praw rządzących światem ${ }^{30}$.

Istotne jest Hume'a naturalistyczne rozumienie człowieka i świata, w którym nie ma miejsca na zdarzenia cudowne. O istnieniu Boga „najwyższej mądrości", można wnioskować pośrednio na podstawie panującej na świecie harmonii ${ }^{31}$. Hume sądzi, że człowiek nie jest bytem wyróżnionym w przyrodzie:

życie ludzkie zależy od tych samych praw, co życie wszystkich innych zwierząt, te zaś podlegają ogólnym prawom materii i ruchu. Zawalenie się wieży czy zadanie trucizny zniszczy człowieka tak samo, jak najnikczemniejsze stworzenie, a powódź zmiecie bez różnicy wszystko, co dostanie się $\mathrm{w}$ zasięg rozszalałej fali. Skoro wtedy życie ludzkie zależy zawsze od ogólnych praw materii i ruchu, to czy pozbawienie się życia jest przestępstwem dlatego, że w każdym przypadku jest przestępstwem wdzierać się w te prawa albo zakłócać ich działanie? ${ }^{32}$

Zatem Hume głosi, że Bóg działa w świecie za sprawą ogólnych i niezmiennych praw, które ustanowił w akcie stworzenia świata, a które wyznaczają ramy wszelkim zdarzeniom i dlatego wszystko dzieje się zgodnie z Jego wolą. Ludzie dysponują pewną niezależnością gdyż są wyposażeni w rozsądek i zdolność podejmowania decyzji, lecz wszystko dzieje się w granicach wyznaczonych ogólnymi, określonymi przez Boga, prawami przyrody ${ }^{33}$. Pozbawienie siebie samego życia nie zakłóca porządku świata i nie może być przestępstwem, przecież: „Nie byłoby z mojej strony przestępstwem, gdybym odwrócił bieg Nilu czy Dunaju, jeżelibym takich rzeczy zdolny był dokonać. Cóż za przestępstwo jest w tym, że ktoś odprowadzi parę uncji krwi z naturalnego ich łożyska?"34. Hume formułuje następujący wniosek:

Zbierając to wszystko, do czegośmy doszli, widzimy, że życie ludzkie zależy od ogólnych praw materii i ruchu, i że zakłócenia lub zmiana ogólnych tych praw nie stanowi zamachu na kompetencje Opatrzności. Czyż nie wynika stąd, że każdy ma pełną swobodę rozporządzania własnym życiem? I że uprawniony jest posłużyć się władza, którą obdarzyła go przyroda? ${ }^{35}$

Hume nie zgadza się z tezą głosząca, że tylko Stwórca jest dysponentem życia człowieka. Jego zdaniem warunkiem koniecznym

\footnotetext{
30 Zob. tamże, 225.

31 Zob. tamże, 224.

32 Tamże, 225-226.

33 Zob. tamże, 225.

34 Tamże, 227.

35 Tamże, 226.
} 
prawdziwości tej tezy jest uczynienie przez Boga na drodze wyjątku szczególnego prawa do dysponowania życiem człowieka, a więc odstąpienie od ustanowionych przez siebie praw kierujących światem ${ }^{36}$. Hume pisze:

Ażeby obalić oczywistość tego wniosku, trzeba by wskazać, dlaczego ten szczególny przypadek miałby być wyjątkiem. Czy może życie ludzkie ma tak wielką wagę, że byłoby zarozumialstwem chcieć nim rozporządzać wedle ludzkiego uznania? Ale życie człowieka znaczy dla wszechświata nie więcej niż życie ostrygi ${ }^{37}$.

Mimo że życie człowieka ma dla niego samego wielką wartość, to jednak w porządku ontologicznym jest nieistotne; życie ludzkiej jednostki jest obojętne dla funkcjonowania przyrody. Jeżeli zaś człowiek sądzi inaczej, to jest to $z$ jego strony niczym nieuzasadniona pycha, a tę można z pewnością przypisać teologom.

Gdyby życie człowieka pozostawało w wyłącznej dyspozycji Boga, to złem byłoby nawet odepchnięcie spadającego na głowę kamienia, co brzmi niedorzecznie. Poddawanie się wyrokom Opatrzności nie oznacza postawy biernej, wręcz przeciwnie - człowiek obdarzony pewnymi umiejętnościami stara się unikać nieszczęść, na przykład buduje dom, uprawia rolę, żegluje, a takie działania nie są przecież w stanie zakłócić porządku świata ${ }^{38}$. Istnieją dwie możliwości: „Wszystkie przeto te czyny są albo jednakowo niewinne, albo jednakowo występne" ${ }^{\prime 39}$. Gdyby były przestępstwem, to człowiek byłby pozbawiony jakiejkolwiek wolności, wszelkie zaś zabiegi podtrzymujące jego trwanie, nawet elementarna zapobiegliwość, byłyby postępowaniem niemoralnym. Skoro zaś sprzeczne jest ze zdrowym rozsądkiem uznanie tych wszystkich czynów za "występne”, to pozostaje druga opcja, to znaczy muszą być one „niewinne”. Wedle Hume'a codzienna ludzka zapobiegliwość i troska o swój los mieszczą się w ustanowionym porządku świata, którego to porządku w żaden sposób nie jest w stanie naruszyć człowiek czy jakiekolwiek zwierzę.

W toku argumentacji filozofa pojawia się jednak następujące zdanie, które być może osłabia siłę jego argumentacji, a mianowicie: „,jeżeli zaś ogólne prawa bywają łamane przez osobne akty woli bóstwa, dzieje się to w sposób, który całkowicie wymyka się ludzkiemu postrzeganiu"40. Jeżeli jest taka możliwość, to w związku z tym teza głosząca szczególną pozycję człowieka w planie boskiej Opatrzności nie musi być fałszywa.

\footnotetext{
36 Zob. tamże, 225.

37 Tamże.

38 Zob. tamże, 226-229.

39 Tamże, 229.

40 Tamże, 225
} 
Teologiczne potępienie samobójstwa jest tak silne, że stanowi źródło nieprzejednanego potępienia go w wymiarze społecznym. Nie wydaje się jednak, aby zakaz formułowany przez teologów był dla samego Hume'a czymś niepokojącym i poruszającym wewnętrznie. Filozof był przekonany o niemożliwości udowodnienia istnienia Boga. Za bezwartościowe uznawał dowody metafizyczne. Nie da się jasno określić, czy był ateista, czy agnostykiem, lecz co istotne, $\mathrm{w}$ jego osobistym nastawieniu nie było wrogości wobec religii. Zdawał on sobie sprawę z tego, że religia jest bardzo ważna dla ludzkości, jednak w nim samym nie wywoływała poruszenia, stanowiąc jedynie zjawisko zewnętrzne. Zdaniem sceptycznie usposobionego Hume’a panujący na świecie ład był właściwie jedyną przesłanką wskazującą na istnienie Stwórcy ${ }^{41}$.

Można jednak zastanawiać się, czy udowodnienie istnienia Boga nakładałoby pewne obowiązki na człowieka, na przykład obowiązek życia aż do naturalnej śmierci. Roman Tokarczyk w swojej interpretacji eseju Hume'a O samobójstwie wskazuje na pewne pomieszanie pojęć dokonane przez chrześcijańskich moralizatorów, gdy mówią o rzekomych obowiązkach wobec Boga:

Dopóki nie odnosimy problemu samobójstwa do Boga, problem obowiązków moralnych mógłby istnieć. $Z$ chwilą jednakże wprowadzenia kategorii Boga wszelkie zakresy wolności jednostkowej zanikają. Niweczy je omnipotencja „absolutnego Pana wszechświata”. Nadto szeroko znane są twierdzenia Hume’a o logicznej niemożliwości wysnuwania powinności moralnych z ustaleń faktograficznych. Nadto więc, gdyby się udało ustalić istnienie Boga, wcale nie wynikałyby jeszcze $\mathrm{z}$ tego żadne zobowiązania etyczne $e^{42}$.

${ }^{41}$ Zob. Frederick Copleston, Historia filozofii, t. 5: Od Hobbesa do Hume'a, przeł. Jarosław Pasek, Joanna Pasek i Paweł Józefowicz (Warszawa: Instytut Wydawniczy Pax, 1997), 264-265 i 268.

${ }^{42}$ Tokarczyk, Prawa narodzin, 276-277. Na temat błędu przechodzenia od faktów do powinności Hume napisał: „W każdym systemie moralności stwierdzałem zawsze, że autor przez pewien czas idzie zwykłą drogą rozumowania, ustala istnienie Boga albo robi spostrzeżenia dotyczące spraw ludzkich, aż nagle i nieoczekiwanie ze zdziwieniem znajduję, iż zamiast zwykłych spójek, jakie znajduje się w zdaniach, a mianowicie »jest « $\mathrm{i}$ »nie jest«, nie spotykam żadnego zdania, które by nie było powiązane słowem "powinien« albo »nie powinien«. Ta zmiana jest niedostrzegalna, lecz niemniej ma wielką doniosłość. Wobec tego bowiem, że to »powinien « albo »nie powinien « jest wyrazem pewnego nowego stosunku czy twierdzenia, przeto jest rzeczą konieczną te zwroty zauważyć i wyjaśnić; a jednocześnie konieczne jest, iżby wskazana została racja tego, co wydaje się całkiem niezrozumiałe, a mianowicie, jak ten nowy stosunek może być wydedukowany z innych stosunków, które są całkiem różne od niego"; David Hume, Traktat o naturze ludzkiej, t. 2, przeł. Czesław Znamierowski (Warszawa: Wydawnictwo PWN, 1963), 259-260. 
Zgodnie z poglądami Hume'a bezsprzeczny dowód na istnienie Boga nie mógłby określać ludzkich obowiązków moralnych wobec Niego, a gdyby było to możliwe, to autonomia moralna człowieka byłaby z nimi sprzeczna.

Hume odnosi się też do potępienia samobójstwa jako sprzeniewierzenia się obowiązkom wobec bliźniego w relacjach społecznych i odrzuca taką możliwość: „Człowiek, który usuwa się z życia, nie czyni społeczeństwu nic złego; przestaje mu jedynie czynić dobro, co jeżeli w ogóle stanowi jakąś szkodę, to jest to szkoda niższego rzędu"43. Nasze społeczne zobowiązania i powinności mają pewne granice. Hume zauważa, że samobójstwo jest aktem odwagi, wręcz może być uznane za czyn chwalebny. Człowiek schorowany, cierpiący, w podeszłym wieku dalszym trwaniem może wyrządzać sobie samemu większą krzywdę, a będąc ciężarem, dobra już nie czyni ${ }^{44}$. Hume nie kwestionował tego, że w społeczeństwie mamy pewne wzajemne zobowiązania moralne, lecz nie są one nieograniczone i nie mogą realizować się kosztem osobistego wielkiego cierpienia: „Ale przyjąwszy nawet, że nasze zobowiązanie do czynienia dobra nie ustaje nigdy, to przecież ma ono z pewnością jakieś granice. Nie jestem zobowiązany wyświadczać społeczeństwu nieznacznego jakiegoś dobra kosztem wielkiej szkody, którą wyrządziłbym samemu sobie" 45 .

Samobójstwo nie jest też zdaniem Hume'a przestępstwem wobec samego siebie. Może być rozumnym działaniem w sytuacji, z której nie ma innego wyjścia:

Że samobójstwo bywa często zgodne z naszym interesem i naszą powinnością względem siebie samych - tego nie może podać w wątpliwość nikt, kto przyznaje, iż podeszły wiek, choroba lub niepowodzenie może uczynić ciężarem i złem gorszym nawet niż własne unicestwienie. Sądzę, że nikt nigdy nie wyrzekł się życia, kiedy warto było jeszcze go się trzymać. Taki bowiem jest nasz naturalny strach przed śmiercia, że mało ważkie powody nie zdołają nigdy nas z nią pogodzićt ${ }^{46}$.

Samobójstwo nie jest ani przestępstwem, ani tchórzostwem: „i rozum, i odwaga skłaniać nas powinny do wyrzeczenia się życia w tej samej chwili, kiedy staje się ono ciężarem" ${ }^{\prime 4}$. Jest to recepta na bycie użytecznym, dawanie przykładu, sposób na zadowalające życie bez niedoli i zagrożeńn ${ }^{48}$.

\footnotetext{
${ }^{43}$ Hume, „Esej”, 231.

${ }_{44}$ Zob. tamże.

45 Tamże.

46 Tamże, 232-233.

47 Tamże, 233.

48 Zob. tamże.
} 
Drugi interesujący nas filozof, James Hillman, o samobójstwie pisze: „Prawo napiętnowało je jako zbrodnię, religia nazywa je grzechem, a społeczeństwo odwraca się od niego. Najczęściej próbuje się je zatuszować lub usprawiedliwić chorobą umysłowa, tak jakby było ono najwyższą aberracją antyspołeczną" ${ }^{49}$. W oparciu o swoją koncepcję duszy ${ }^{50}$ wspiera i uzupełnia psychoanalitycznym punktem widzenia racjonalne podejście Hume'a do zagadnienia samobójstwa, to znaczy traktuje je jako fakt rzeczywistości psychicznej. Hillman poszukuje źródeł potępienia, czyli tego, "do jakich korzeni - pozytywnych bądź negatywnych - odwołują się argumenty dotyczące samobójstwa. Korzeniami tymi są poglądy psychologiczne, te zaś wyrastają z obrazów myślowych i wyobrażeniowych tych dziedzin, w których ma miejsce najbardziej zagorzała dyskusja na temat samobójstwa" ${ }^{51}$. Hillman uważa, że źródłem naszych idei są "wyobrażeniowe obrazy bazowe” i materiał doświadczenia jest porządkowany przez perspektywę archetypową. Archetypy są tu rozumiane jako aksjomatyczne i autonomiczne obrazy na podobieństwo paradygmatów czy pierwszych zasad ${ }^{52}$. Poszukując źródeł zakazu w kontekście socjologicznym, prawnym, teologicznym i medycznym, dochodzi do wniosku, że wszystkie te dziedziny opierają się na właściwym sobie modelu myślowym, wszystkie implikują potępienie samobójstwa a priori. Dogmatyczne źródła zakazu są nieprzejednane wobec racjonalnej argumentacji.

Odnosząc się krytycznie do zakazu samobójstwa, Hume opiera się na zastanych ideach, które poddaje gruntownej analizie, natomiast Hillman sięga do samych korzeni naszego postrzegania i rozumienia świata ${ }^{53}$. Hillman pisze:

Tradycyjne podejście opiera się na wielu ważkich argumentach i jest z pewnością bardzo stare; wymaga jednak ponownej weryfikacji z pozycji całkowicie postronnej. Niektórzy myśliciele już tego dokonali; byli to przede wszystkim Donne, Hume, Wolter, Schopenhauer, ci jednak nie są nowocześni: brak im stanowiska psychologicznego, które rozpatruje

49 Hillman, Samobójstwo, 12.

${ }^{50}$ Na temat pojęć „psyche” i „dusza” Hillman pisze: „Wyrażenia psyche i dusza znaczą to samo, obecnie obserwujemy jednak wyraźną tendencję do unikania wieloznaczności słowa dusza poprzez stosowanie bardziej biologicznego i nowocześniejszego określenia psyche. Psyche to słowo używane raczej na określenie naturalnego zjawiska towarzyszącego życiu psychicznemu, z którego być może nawet wynika. Słowo dusza zawiera natomiast podteksty metafizyczne i romantyczne. Graniczy ono z domeną religii"; Hillman, Samobójstwo, 50.

51 Tamże, 21.

52 Zob. Hillman, Re-wizja, 30.

${ }_{53}$ Zob. tenże, Samobójstwo, 22 i 24. 
same bazowe obrazy wyobrażeniowe, zamiast dyskutować idee dotyczące samobójstwa wyrastające wszak dopiero z tych obrazów ${ }^{54}$.

Wynika stąd, że obydwaj myśliciele, Hume i Hillman, wykazują inne podejście $w$ swoich rozważaniach na temat zakazu samobójstwa i w ten sposób ich poglądy mogą się uzupełniać.

Hillman, tak jak Hume, nie zgadza się z potępieniem samobójstwa przez teologów chrześcijańskich:

Nie możemy sobie odebrać życia, gdyż nie należy ono do nas. Jest ono częścią boskiego aktu stworzenia, a my jego stworzeniami. Ten, kto wybiera śmierć, odrzuca świat stworzony przez Boga i wypiera się tego, że jest jego stworzeniem. Kto sam decyduje o tym, kiedy ma nastąpić chwila jego śmierci, okazuje coś niesłychanego: pychę. Odbiera Bogu wyłączną władzę sądzenia o życiu i śmierci ${ }^{55}$.

Hillman zadaje pytanie: „Dlaczego samobójstwo tak bardzo dręczy teologię?”, i odpowiada: „Samobójstwo nie przeczy bowiem ani Bogu, ani religii, a jedynie roszczeniu teologii do decydowania, jaką śmiercią mamy umierać. Samobójca udowadnia teologii, że nie obawia się jej starych broni, zaświatów i Sądu Ostatecznego. Jednakże z tego, że samobójstwo jest antyteologiczne, nie wynika wcale, iż musi być ono niereligijne" ${ }^{\prime 56}$. Hillman nie utożsamia teologii z religią i wskazuje na autorytatywne zapędy teologów, którzy zajmując nieprzejednaną postawę w kwestii samobójstwa, obawiają się przede wszystkim groźby anarchii, jako że samobójca swoim czynem odrzuca opinię teologii, samodzielnie szukając drogi do Boga ${ }^{57}$. To nie samobójca wykazuje pychę, jest wręcz odwrotnie. Hillman, tak jak Hume, przypisuje ją teologom, dodatkowo wskazując, co jego zdaniem ich motywuje.

Zarówno Hume, jak i Hillman kwestionują tezę, że śmierć może przyjść tylko z "zewnątrz". Zgadzają się również co do tego, że Bóg mógłby dać ludzkiej duszy wewnętrzny impuls do umierania. Hillman pisze:

W Księdze Mądrości Salomona czytamy, że jest czas umierania (III, 2). Jeżeli Bóg zna ten czas, jak obwieszcza go człowiekowi? Teologia chce, byśmy wierzyli, że Bóg potrafi przemawiać tylko poprzez ciosy losu, a śmierć może przyjść tylko z zewnątrz. Również z takiej perspektywy

54 Tamże, 37. Ponadto Hillman wychodzi z założenia, że gdyby okazało się, że danego modelu myślowego opartego na właściwym sobie obrazie bazowym nie dało się uzgodnić z uzasadnieniem czynu suicydalnego, to okazałoby się, że tak naprawdę tym, co jest właściwym źródłem zakazu, jest po prostu lęk przed śmiercią.

55 Tamże, 30-31.

56 Tamże, 31-32.

57 Zob. tamże, 30-32. 
śmierć jest - podobnie jak dla socjologii i prawa - bytem egzogenicznym, może nam ją zadać tylko świat zewnętrzny: wróg, nieszczęśliwy wypadek, choroba. Nie nosimy jej w sobie; nie żyje ona w duszy ${ }^{58}$.

Hillman, tak samo jak Hume, sądzi, że Bóg może sygnalizować człowiekowi czas nadejścia jego śmierci, przemawiając do samej duszy. W tej kwestii sam wskazuje na zbieżność swoich poglądów z Hume'em, którego cytuje: „Kiedy się przebijam własnym mieczem, otrzymuję tak samo śmierć z rąk istoty boskiej jak wówczas, gdy dosięga mnie ona w paszczy lwa, na dnie przepaści czy w gorączce" ${ }^{159}$.

Hillman uważa Biblię za obraz wyobrażeniowy znajdujący się u podstaw prawnych zakazów i sposobów zapobiegania samobójstwom, uzasadniając to tym, że prawo religijne jest pierwotne wobec świeckiego. Podstawę poglądu prawnego i teologicznego stanowi przykazanie „Nie zabijaj”60. Pisze: „Nie tylko prawo, ale i teologia nakazuje nam żyć"61. Kwestionuje samo źródło potępienia i - tak jak Hume - nie zgadza się z Augustynem, według którego samobójstwo jest rodzajem zabójstwa. Hillman zauważa, że "prawo” nakazuje człowiekowi żyć nawet wbrew jego poczuciu losu. Prawo chroni pewne wolności człowieka, również prawo własności, lecz ochronie nie poddaje możliwości dobrowolnej rezygnacji z życia ${ }^{62}$. Hillman wskazuje na pewien paradoks, zauważając, że „w myśl tradycji prawnej możemy zabijać innych na różne sposoby i z różnych powodów, nie łamiąc przy tym prawa; to jednak, że zabijamy samych siebie, nie może być w żadnych okolicznościach usprawiedliwione ani przebaczone. Obowiązuje zasada: »Nie mogę być katem samego siebie «"63. Samobójca łamie umowę społeczną łamie prawo, ponosi winę i nie ma żadnej możliwości usprawiedliwienia. Hillman wskazuje na pewną „furtkę prawną", a mianowicie jest nią pomieszanie zmysłów, zaburzenia psychiczne, brak racjonalnego osądu. Taki samobójca okazuje się niezdolny do przestrzegania umowy społecznej opartej na zasadach rozsądku, więc jego czyny nie naruszają zasad społecznych ${ }^{64}$. Zauważa przy tym, że w teologicznych, społecznych, prawnych i medycznych schematach myślowych nie ma odpowiedniego miejsca na refleksję na temat śmierci:

Dla nich śmierć pozostaje poza życiem; nie żyje w duszy, nie jest stale obecna, prowokującą do podjęcia decyzji możliwością. Gdyby to uznały,

\footnotetext{
58 Tamże, 31.

59 Tamże, 32. Zob. Hume, 32.

${ }_{60}$ Zob. Hillman, Samobójstwo, 29.

61 Tamże.

${ }^{62}$ Zob. tamże, 28 i 29.

63 Tamże, 28.

${ }^{64}$ Zob. tamże, 28 i 29.
} 
musiałyby się pogodzić z możliwością usprawiedliwienia samobójstwa, a w ten sposób pogrzebałyby swoją pozycję. Zarówno społeczeństwo, jak i prawo, Kościół i życie straciłyby grunt, na którym się opierają ${ }^{65}$.

Hillman na przykładzie socjologicznego obrazu bazowego, jakim jest „społeczeństwo", najlepiej wyjaśnia, czym jest ów "bazowy obraz wyobrażeniowy"66. Mianowicie dla socjologa jest „żywą rzeczywistością", źródłem modelu myślowego, w którego ramach weryfikowane są hipotezy, zostaje skonstruowana dziedzina faktów, czyli ów model myślowy determinuje rozumienie natury społeczeństwa. $W$ rezultacie warunki społeczne doprowadzające jednostkę do samobójstwa są oceniane zawsze negatywnie, ponieważ czyn suicydalny oddziałuje destrukcyjnie na strukturę społeczną, osłabiając ją i dezintegrując relacje grupowe. W socjologii samounicestwienie jest przeciwieństwem bazowego obrazu wyobrażeniowego, jest aktem wrogim społeczeństwu, jest tym, co należy bezwzględnie zwalczać. W związku z tym, że bazowe obrazy oddziałują na postawę człowieka z jego nieświadomości ${ }^{67}$, to cechuje je pewien dogmatyzm i wpływ racjonalnych argumentów może być znikomy.

Hillman na podstawie istnienia zarówno ogromnej różnorodność motywów, jak i sposobów pozbawiania się życia stwierdza, że samobójstwo jest możliwością, którą człowiek może wybrać; każda decyzja o odebraniu sobie życia ma swój wewnętrzny sens z punktu widzenia duszy, abstrahujący od zewnętrznych klasyfikacji socjologów. Ponadto sądzi, że każdy z nas może stać się suicydalny, gdy tylko pojawią się pewne okoliczności i wówczas dusza będzie tak bardzo ogarnięta dążeniem do unicestwienia, że wszelkie zakazy okażą się nieskuteczne, a temu niestety czasami nie można zapobiec. Śmierć żyje w duszy, człowiek nosi ją w sobie ${ }^{68}$. Hillman zgadza się z opinią socjologa Emile’a Durkheima głoszącego, że: „Przyczyny śmierci leżą raczej poza nami samymi niż w nas i stają się skuteczne tylko wówczas, kiedy znajdziemy się w zakresie ich działania"69.

Hume i Hillman zastanawiają się także nad samym procesem decyzyjnym, jaki zachodzi w duszy człowieka - procesem doprowadzającym

65 Tamże, 36.

66 „Bazowe obrazy wyobrażeniowe nie mogą być dowolnie podejmowane i odkładane na bok. Są one przesycone tradycją i przekazywane przez samą tradycję zawodu, toteż od chwili, w której podchodzimy do problemu zawodowego, przejmujemy archetypową rolę. Wszędzie tam, gdzie żywa jest tradycja, jej archetypowe tło daje oparcie wszystkim tym, którzy są z nią związani. Pod wieloma względami tło owo jest silniejsze od indywiduum i istotnie przyczynia się do skuteczności zawodowych starań jednostki"; Hillman, Samobójstwo, 22.

67 Zob. tamże, 22-24.

68 Zob. tamże, 31 i 43.

69 Tamże, 23-24. 
do samobójstwa. Hume nie ma wątpliwości, że człowiek, który decyduje się targnąć na własne życie, bardzo boi się śmierci, a realizacja tragicznej decyzji o zakończeniu swojego życia wymaga od niego heroicznej odwagi. Gdy coś stanie na przeszkodzie wykonaniu samobójczego zamiaru, na przykład przyjaciel powodowany najlepszymi intencjami, to do ponownej próby może nie dojść ze względu na paraliżujący lęk. Hume pisze:

Śmierć przeraża nas tak bardzo, że kiedy zjawi się nam w postaci innej niż ta, z którą człowiek usiłował oswoić wyobraźnię, strach staje się jeszcze okropniejszy i bierze górę nad wątłą ludzką odwagą jeżeli zaś z przyrodzoną tą bojaźnią łączą się jeszcze okropności, którymi grozi nam zabobon, to nic dziwnego, że pozbawia to ludzi całkowicie wszelkiej władzy nad własnym życiem; wszak nieludzki ten tyran wydziera nam wiele nawet takich przyjemności i uciech, do jakich pociagga nas silna skłonnośćc ${ }^{70}$.

W poglądach Hume'a decyzja o rezygnacji z życia wydaje się pewnego rodzaju przepełnioną dramatyzmem „kalkulacją": czy żyć i cierpieć, czy nie istnieć i już niczego nie odczuwać? Oczywiście taki punkt widzenia można przypisać człowiekowi, który nie wierzy w dalsze trwanie, a więc niemożliwość odczuwania po śmierci ciała. W przypadku osoby wierzącej dochodzi groźba wiecznego potępienia, wzmagająca jeszcze bardziej tragizm procesu decyzyjnego. Lęk przed potępieniem może sprawić, że człowiek będzie jednak trwał w cierpieniu.

Wybór śmierci nie jest łatwą kalkulacją zysków i strat, która miałaby pochopnie skłaniać człowieka do rezygnacji z życia. Taki sam pogląd głosił Lucjusz Anneusz Seneka, rzymski stoik:

Także ze względu na boleść nie zadam sobie gwałtu: umrzeć w ten sposób znaczy tyle, co dać się zwyciężyć. Gdybym wiedział wszelako, że będę musiał znosić boleść stale, odejdę - nie dla samego bólu, lecz dlatego, że będzie mi przeszkadzał we wszystkim, co jest celem życia. Słaby to człowiek i tchórz, kto śmierć zadaje sobie z powodu bólu, ale głupi, kto żyje tylko po to, by znosić ból ${ }^{71}$.

Autentycznym przejawem ludzkiej wolności jest prawo człowieka do rezygnacji z życia. Hołyst wpisuje Hume'a w pewien ciąg filozoficznej refleksji - zaczynając od Arystypa poprzez Epikura aż do Seneki w której nie ma miejsca na przymus życia. Decyzja samobójcza może być rezultatem zajścia szeregu niekorzystnych okoliczności, gdy zaś

${ }^{70}$ Hume, „Esej”, 222-223.

${ }^{71}$ Lucius Annaeus Seneca, Listy moralne do Lucyliusza, 58, 36, przeł. W. Kornatowski (Warszawa: Wydawnictwo PWN, 1961), 205-206. 
spiętrzenie przeciwności losu jest tak duże, to rozumną reakcją może być świadome i spokojne odejście z życia ${ }^{72}$ :

W sformułowanym w myśli Arystypa i Epikura, a następnie rozwijanym w poglądach Hume'a, Benthama i J. S. Milla, eudajmonizmie naczelny motyw postępowania moralnego sprowadzał się zawsze do pogoni za szczęściem osobistym. Dopiero gdy kierowana zasadą eudajmonizmu aktywność stawała się niejako fizycznie niemożliwa, gdy zaczynało brakować sił w biegu, można było dobrowolnie i ostatecznie owe „zawody z życiem" przerwać ${ }^{73}$.

Natomiast Hillman, jako psycholog głębi, podaje w wątpliwość to, że człowiek sam najlepiej rozumie swoje życie i śmierć: „Przeciętny człowiek rozumie niewiele $\mathrm{z}$ tego, co czyni, ponieważ zaś śmierć najczęściej go zaskakuje, zdaje mu się, że przychodzi ona z zewnątrz"74. Tak samo jest $\mathrm{w}$ przypadku innych treści psychicznych, które nie znajdują się $\mathrm{w}$ naszej świadomości. Uznajemy więc, że pochodzą z zewnątrz. Człowiek jest świadomy swojej osobowości tylko częściowo, do zrozumienia potrzebne jest poznanie jego fantazji mitycznych sytuujących się $\mathrm{w}$ nieświadomości. To może być dokonane przez psychoanalityka: „Żaden z motywów samobójczych [...] - zbiorowy, emocjonalny, intelektualny - nie przenika pod powierzchnię, nie dociera do wewnętrznej domeny śmierci. [...] aby zrozumieć samobójstwo, musimy wiedzieć, jakie fantazje mityczne mu towarzyszą". Zdaniem Hillmana samobójstwo popełnione z pełną świadomością jest niezwykle rzadkie; przykładem może być śmierć Sokratesa czy Seneki ${ }^{75}$.

Hołyst sądzi, że samobójstwo jest zazwyczaj uważane za rodzaj śmierci dobrowolnej, a w związku z tym rozpatrywane w kategoriach procesu decyzyjnego, a zatem działania świadomego. Przy czym zauważa, że kwestia, czy rzeczywiście akt ostateczny jest zawsze rezultatem w pełni świadomej decyzji, może być podana w wątpliwość ${ }^{76}$. Nie należy jednak sądzić, że ktoś, kto bardzo cierpi i chce zakończyć nieznośny ból, jest osobą całkowicie pozbawioną racjonalnego osądu sytuacji. Jan Hartman ujmuje tę myśl następująco:

Prawie niemożliwością jest postawić się w sytuacji kogoś, kto cierpi tak bardzo, że pragnie śmierci. Nie wolno jednak uważać takich osób za niespełna rozumu, jak to się nieraz sugeruje. Byłoby to aroganckie w stosunku do człowieka, który z pełną świadomością i konsekwentnie twierdzi,

${ }^{72}$ Zob. Hołyst, Suicydologia, 141.

73 Tamże, 138.

${ }^{74}$ Hillman, Samobójstwo, 56.

75 Zob. tamże, 55-56.

76 Zob. Hołyst, Suicydologia, 44. 
że nie chce już dłużej żyć, gdy nie może pogodzić się z fatalną jakością swojego życia ${ }^{77}$.

Hillman pisze: „Samobójstwo jest najbardziej niepokojącym problemem życiowym. [...] Jak je zrozumieć? Dlaczego ktoś popełnia samobójstwo? Dlaczego ktoś go nie popełnia? Samobójstwo przybiera postać nieodwołalnego zniszczenia i pozostawia po sobie winę, wstyd i beznadziejne niezrozumienie" ${ }^{\prime 78}$. Być może poglądy Hillmana i Hume'a w jakiejś mierze wpisują się w nurt samobójstwa egzystencjalnego, czyli takiego, które nie jest rezultatem konkretnej sytuacji, lecz doświadczeniem absurdu egzystencji. Hume, mimo że dostrzega na świecie ład, który może stanowić przesłankę na rzecz istnienia Stwórcy, w Dialogach o religii naturalnej pisze:

Samo przyjście na świat jest udręką dla noworodka i dla jego umęczonej matki; każdemu okresowi życia towarzyszą słabość, niemoc i cierpienie; i kończy się ono wreszcie w śmiertelnej męce i grozie. Zauważ także, rzekł Filon, jak osobliwe zabiegi stosuje przyroda, ażeby życie każdej żywej istoty zaprawić goryczą. Silniejszy żeruje na słabszym i utrzymuje go w ciągłym strachu i lęku. Słabszy z kolei żeruje na silniejszym, dręczy go i napastuje bez wytchnienia. Weź pod uwagę nieprzebrany rój owadów, które albo żyją na ciele zwierzęcia, albo fruwając dokoła, topią w nim żądła. Owady te same z kolei znoszą męki od innych owadów jeszcze mniejszych. Tak więc każde zwierzę ze wszystkich stron, z przodu i z tyłu, z góry i z dołu, otoczone jest przez wrogów, którzy nieustannie szukają jego nieszczęścia i zguby ${ }^{79}$.

Zarówno Hume, jak i Hillman nie głoszą pochwały samobójstwa, nikogo też do niej nie zachęcają. Natomiast bezwzględne potępianie tego czynu, szczególnie na gruncie teologii, uznają za sprzeczne ze zdrowym rozsądkiem, z ludzką autonomią moralną, własnym poczuciem losu. W związku z tym uważają że czyn suicydalny jest w pewnych okolicznościach usprawiedliwiony, a wręcz stanowi rozumne działanie. Śmierć można wybrać w sytuacji cierpienia, utraty godności czy poczucia sensu dalszego trwania. Hillman z perspektywy psychologicznej, uzupełniającej poglądy Hume’a, głosi, że czasami nie można zapobiec samobójstwu, choć nie oznacza to, że ten czyn jest zawsze rezultatem zaburzeń psychicznych.

77 Jan Hartman, Bioetyka dla lekarzy (Warszawa: Wydawnictwo Wolters Kluwer, 2009), 121-122.

${ }_{78}$ Hillman, Samobójstwo, 11.

79 Hume, Dialogi, 89-90. 


\section{Bibliografia}

Augustyn. 2015. Państwo Boże, przeł. ks. Tadeusz Kubicki. Kęty: Wydawnictwo Marek Derewiecki.

Chwin Stefan. 2016. Samobójstwo jako doświadczenie wyobraźni. Gdańsk: Wydawnictwo Tytuł.

Copleston Frederick. 1997. Historia filozofii. T. 5: Od Hobbesa do Hume'a, przeł. Jarosław Pasek, Joanna Pasek, Paweł Józefowicz. Warszawa: Instytut Wydawniczy Pax.

Cyceron Marek Tuliusz. 1960. „O wróżbiarstwie”. W: Marek Tuliusz Cyceron. O naturze bogów; O wróżbiarstwie; O przeznaczeniu, przeł. Wiktor Kornatowski. Wydawnictwo Naukowe PWN: Warszawa.

Drozdowicz Zbigniew. 2006. Filozofia Oświecenia. Warszawa: Wydawnictwo Naukowe PWN.

Gilson Etienne. 1998. Tomizm. Wprowadzenie do filozofii św. Tomasza z Akwinu, przeł. Jan Rybałt. Warszawa: Instytut Wydawniczy PAX.

Hartman Jan. 2009. Bioetyka dla lekarzy. Warszawa: Wydawnictwo Wolters Kluwer.

Hillman James. 1996. Samobójstwo a przemiana psychiczna, przeł. Dariusz Rogalski. Warszawa: Wydawnictwo KR.

Hillman James. 2014. Kod duszy. W poszukiwaniu charakteru człowieka i jego powołania, przeł. Jerzy Korpanty. Warszawa: Wydawnictwo Laurum.

Hillman James. 2016. Re-wizja psychologii, przeł. Jerzy Korpanty. Warszawa: Wydawnictwo Laurum.

Hołyst Brunon. 2012. Suicydologia. Wydanie 2. Warszawa: Wydawnictwo LexisNexis.

Hume David. 1962. Dodatek „Esej o samobójstwie”. W: David Hume, Dialogi o religii naturalnej. Naturalna historia religii wraz z dodatkami, przeł. Anna Hochfeldowa, 221-233. Warszawa: Wydawnictwo PWN.

Hume David. 1963. Traktat o naturze ludzkiej, przeł. Czesław Gabriel Stanisław Znamierowski. Warszawa: Wydawnictwo PWN.

Kopania Jerzy. 2003. Boski sen o stworzeniu świata. Szkice filozoficzno-teologiczne. Białystok: Wydawnictwo Trans Humana.

Machinek Marian MSF. 2001. Śmierć w dyspozycji człowieka. Teologia moralna wobec problemów etycznych u kresu życia ludzkiego. Olsztyn: Wydawnictwo Wyższego Seminarium Duchownego Metropolii Warmińskiej „Hosianum".

Platon. 1999. „Fedon”. W: Platon, Dialogi. T. 1, przeł. Władysław Witwicki. Kęty: Wydawnictwo Antyk.

Seneca Lucius Annaeus. 1961. Listy moralne do Lucyliusza, 58, 36, przeł. Wiktor Kornatowski. Warszawa: Wydawnictwo PWN.

Ślęczek-Czakon Danuta. 1994. „Etyka Davida Hume'a: założenia, wnioski, możliwości interpretacyjne". Folia Philosophica 12: 125-142.

Tokarczyk Roman. 1984. Prawa narodzin, życia i śmierci. Etyczne problemy wspótczesności. Lublin: Wydawnictwo Lubelskie. 
Tomasz z Akwinu. 2006. Suma teologiczna w skrócie. Warszawa: Wydawnictwo Antyk - Marcin Dybowski.

\section{Streszczenie}

Celem rozważań jest ukazanie zbieżności poglądów Davida Hume’a i Jamesa Hillmana w kwestii nieracjonalności potępiania samobójstwa w wymiarze religijnym, społecznym i jednostkowym. Okazuje się, że źródłem zakazu są przede wszystkim dogmatyczne twierdzenia teologów odmawiających człowiekowi autonomii moralnej. Przedmiotem analizy jest esej Hume'a O samobójstwie i książka Hillmana Samobójstwo a przemiana psychiczna.

Słowa kluczowe: Hume, Hillman, samobójstwo

\section{David Hume and James Hillman on the Irrationality of Condemning Suicide}

\section{Summary}

The aim of the deliberations is to show the concurrence of views between David Hume and James Hillman on the irrationality of condemning suicide in religious, social, and individual aspects. It appears that the source of the ban are primarily dogmatic claims by theologians denying a man's moral autonomy. The subjects of the analysis are D. Hume's essay On Suicide and J. Hillman's book Suicide and the Soul.

Keywords: Hume, Hillman, suicide 